\title{
Development of an Instructional System for Introductory Agricultural Economics
}

\author{
by \\ Alan Evans, Kelso Wessel, Donald Larson and \\ Edward Powers*
}

*Evans is Consultant for Instructional Media Development in the Teaching Aids Laboratory, Associate Professors Wessel and Larson and Graduate Student Powers are in the Department of Agricultural Economics and Rural Sociology, The Ohio State University, Columbus, Ohio 43210.

The promise of educational media rests upon the premise that technology can provide a mechanical or electronic advantage which will permit educators to teach more students for less while maintaining or even improving the quality of education. The objective has not been to replace the teacher with a machine but to free the teacher from the routine administrative functions, the monitoring of drill and practice and the simple presentation of factual information.'

\section{Introduction}

This article describes the expansion of an instructional system for a survey course in economics at The Ohio State University. Food Fiber and Natural Resource Economics (AEC 100) is taught primarily to freshman and sophomore students whose interests are in agriculture or natural resources. Approximately 1,200 students take AEC 100 each year. Due to the varied backgrounds of students and the large enrollment, optional study materials have been developed to supplement the lectures and text. These study materials also help students unable to fully understand the content as presented in the lectures and/or text and serve as a means of standardizing the course content among the five professors who teach the course.

Over the past four or five years, a series of homework problems related to concept application in economics has been assembled in a workbook which is made available to students. Traditionally, these problems were graded by the professor. However, due to increasing student enrollment, it became impossible to grade each set of problems and provide any explanation of the concepts involved. Because of the learning value placed on the problem sets by students, a technique was needed to reach an increasing number of students and free the teacher from repetitive routines.

\section{Development}

A successful instructional model was being used by the Mathematics Department at O.S.U. which had for many years used instructional television on a large scale. Their precalculus and introductory calculus course 
sequence is very individualized with testing and retesting both tied directly into the program. ${ }^{2}$ The viability of this individualized study system has been documented, both in cost of the instructional technology and its acceptance by students. ${ }^{3}$ Mathematics students individually use video taped lectures and problem tapes with solutions, as needed, and at their own pace and convenience. It was decided, therefore, that solutions to economic problems should be placed on videocassette tapes to assist students who needed further explanation.

Until the introduction of videocassettes, the resources available in AEC 100 consisted of a workbook and four CAI programs. The workbook consisted of 11 major units, each essentially corresponding with a different topic taught in the course. CAl programs covered four of the 11 units.

Several Agricultural Economics faculty members worked with the staff of the Telecommunications Center at O.S.U. to produce six 30minute videocassettes. Broadcast quality studios were used in the production and student copies duplicated on videocassette. The student went to a circulation desk in the Learning Resources Center to sign out a videocassette for use in nearby study carrels. Each carrel is equipped with a small screen television attached to a videocassette player. These self-threading videocassette players operate with push-buttons providing the student the option of stopping, reversing the cassette tape, and reviewing as frequently as necessary. Upon completion the tape is rewound and returned to the circulation desk.

\section{Evaluation}

In an effort to evaluate the effectiveness of the videocassettes a section of 160 students was told that they were to be involved in an evaluation of the resources available to them and that the class would be divided into two groups. On alternating weeks each group would have access to the videocassette relating to the unit being studied.

A quiz was given covering the material for each study unit. After each quiz, the students completed a questionnaire which indicated what resources had been used and their evaluation of them. A separate evaluation was used at the end of the quarter, and various statistical techniques were used to evaluate the effect of the resources on student grades.

At the end of the quarter, students were asked how, in their opinion, the videocassettes could be improved. As one would expect not all students were completely satisfied; however, most reacted favorably. Some of the responses were:

"Helped to get ideas and definitions straight without rushing."

"The videocassette explained how the answers could be derived for each question, which was helpful."

"It explained the answers better. I could concentrate better with the videocassettes and I enjoyed them." 
"In just using the workbook answer key you find the answers to the problems but not the reasoning behind them. By using the videocassette someone is explaining the reason behind the correct answer."

It is significant to note that negative replies to the open ended question of how the videocassettes could be improved were only three percent as frequent as the positive replies. A few specific examples of negative reactions to the videocassettes were:

"Make the presentations more interesting."

"Expand the discussion beyond the workbook and add more examples."

"More information and examples would be better."

"Too repetitious."

At the end of the quarter, students were asked to rank each videocassette unit on a scale of one through five, with one being the highest mark. Almost half (49 percent) of the students felt the videocassettes were beneficial and ranked the units as 1 or 2 .

\section{Correlation Between Videocassette Usage and Test Scores}

To compare the results obtained by those who used the videocassettes with those who did not, an analysis of variance of the quiz grades was used. No significant differences among the means between groups was found. In another attempt to relate the effectiveness of the program to the final examination grades, the students were divided into three separate groups according to their final exam score. Students with good final exam scores found the videocassette programs least effective. Eighty-seven percent of the average students rated the programs either very good or good, and about 80 percent of the below average students rated the videocassette programs good or very good. In all, more than $\mathbf{9 0}$ percent of the students responding indicated that the videocassettes were effective. However, a Chi-Square analysis indicated that the results were not significant.

\section{Summary}

Students who used the videocassette program did not obtain better grades on quizzes than the non-users. The main factor which might account for this lack of a measurable difference was the experimental design. The experimental design only controled for the impact of the program on quiz grades. An equivalent control group with no access to videocassettes would have allowed an assessment of videocassette impact using midterm and final exams. This was not done so we could be fair to all students by providing them the opportunity to use some of the videocassettes during the quarter. Additionally, student access to lectures, text and CAI would have reduced the measurable impact of videocassettes.

NALLD Journal 
Such lack of experimental control is frequently a fact of life for instructional developers working to revise ongoing courses. Nevertheless, the developer must continue to gather any evidence that will help shape a more effective instructional system.

In conclusion, the videocassettes are an important supplement for students who encounter difficulty understanding the concepts from traditional type lectures. Student reaction to the videocassettes was very favorable from those who used them. Almost one-half of the students rated the videocassettes either good or excellent in terms of usefulness. The lowest ratings were from those students who were high achievers and perhaps did not need the additional resources. Finally, the videocassettes expanded a teaching system by providing an alternative means of study that was well received by many students and accomplished a major goal by freeing the instructor for individual student contact.

\section{REFERENCES}

1. Andrew Molner, "Ten Years of Educational Broadcasting," Educational Broadcasting Review, (June, 1969), Vol. 3.

2. John Riner and Bert Waits, "Television and Videocassettes for Math at Ohio State," Videoplay Magazine, (October 1973).

3. Alan Evans, "Costing A Videocassette Learning System," Audiovisual Instruction, (January, 1975).

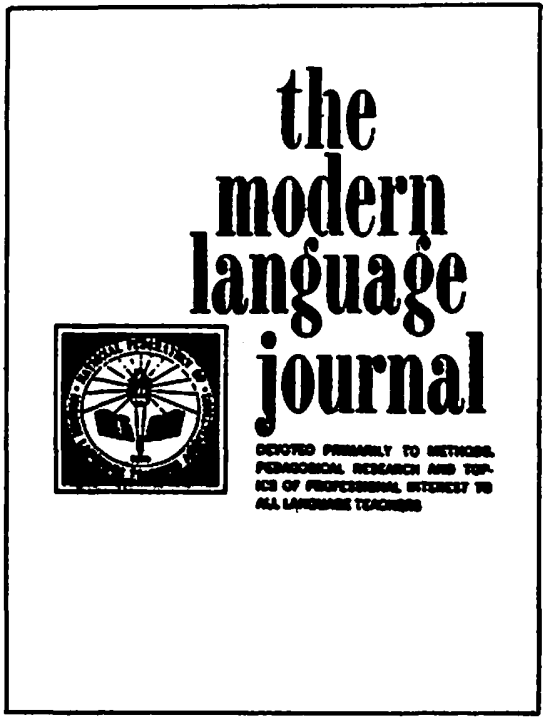

"The outstanding joumal of medern langusage teacting in the United States" stimulating articles pedagogical research reviews of textbools and teaching aids useful bibliographies timely announcements current advertisements

Edited by Charles L. King. The University of Colorado, Boulder. Colorado. Published by The National Federation of Modern Language Teachers Associations.

Six issues a year (September through April) . . . individual subccription 87.00, institutions and foreign arbcriptions $\$ 8.00$ (net in USA fund). Sample copy on requeat.

The Medern Langunge Journal Wallace G. Klein, Business Manager 13149 Cannes Drive

St. Louis, Missouri 69141 